\title{
STRATEGIC OF ENTREPRENEURSHIP RETAIL BUSINESS SECTOR IN BOGOR CITY
}

\author{
Intan Azizka*11 and Lindawati Kartika*) \\ *) Departement of Management, Faculty of Economics and Management, IPB University \\ Jl. Agatis, Campus IPB Dramaga Bogor 16680, Indonesia
}

\begin{abstract}
Retail growth as one of the most important distribution chains in the product distribution cycle is a great opportunity for retail businesses. On the other hand, retail growth also brings increasing business competition, so it needs strategic planning. One method that can be used is strategic entrepreneurship which combines two theories, namely strategic management and entrepreneurship to maximize opportunities by creating competitiveness in business processes. This study aims to analyze the characteristic of the retail business sector in Bogor City, strategic entrepreneurial factors and the influence between Input-Process-Output segmentation using descriptive analysis methods and Structural Equation Modeling - Partial Least Square (SEM-PLS). The type of data used in this research is quantitative by using primary data in the form of interviews and filling out questionnaires and secondary data using literature studies and previous research. This research was conducted from December 2019 to May 2020 with a total of 85 retail respondents. The results showed that modern retail in the city of Bogor is included in starting a business and dominated by incorporated company. Retail in Bogor City is also dominated by women as top management and senior high school graduates. There were 6 strategic entrepreneurial factors namely environmental factors, organization resources, individual resources, resource orchestration, consumer value and competitive advantages, creating wealth and other benefits. The variables that have a positive and most significant influence were consumer value and competitive advantages. Variables that did not have a significant effect is individual resources.
\end{abstract}

Keywords: descriptive analysis, input-proses-output, retail, SEM-PLS, strategic entrepreneurship

\begin{abstract}
Abstrak: Pertumbuhan ritel sebagai salah satu mata rantai distribusi terpenting dalam siklus pendistribusian produk menjadi peluang besar bagi pelaku usaha ritel. Disisi lain, pertumbuhan ritel juga menghadirkan persaingan bisnis yang semakin meningkat sehingga perlu untuk merancang perencanaan yang strategis. Salah satu metode yang bisa digunakan adalah kewirausahaan strategis yang menggabungkan dua teori yaitu strategi manajemen dan kewirausahaan untuk memaksimalkan peluang dengan menciptakan daya saing dalam proses bisnis. Penelitian ini bertujuan untuk menganalisis karakteristik ritel di Kota Bogor, faktor-faktor kewirausahaan strategis dan pengaruh antar segmentasi Input-Proses-Output dengan menggunakan metode analisis deskriptif dan Structural Equation Modeling-Partial Least Square (SEM-PLS). Jenis data yang digunakan dalam penelitian ini adalah kuantitatif dengan menggunakan data primer berupa wawancara secara langsung dan pengisian kuesioner serta data sekunder menggunakan studi literatur dan penelitian terdahulu. Penelitian ini dilaksanakan pada bulan Desember hingga Mei 2020 dengan total 85 responden ritel. Hasil penelitian menunjukkan ritel modern di Kota Bogor termasuk kedalam kategori perintisan usaha dengan didominasi oleh Perseroan Terbatas. Ritel di Kota Bogor juga didominasi oleh perempuan sebagai top management dan lulusan SMA. Terdapat 6 faktor kewirausahaan strategis yaitu faktor lingkungan, sumberdaya organisasi, sumberdaya individu, orkestrasi sumberdaya, penciptaan nilai dan keunggulan bisnis, dan penciptaan kekayaan dan manfaat lainnya. Variabel yang memiliki pengaruh positif dan paling signifikan adalah penciptaan nilai dan keunggulan bisnis. Variabel yang tidak berpengaruh signifikan yaitu sumberdaya individu.
\end{abstract}

Kata kunci: analisis deskriptif, input-proses-output, ritel, SEM-PLS, kewirausahaan strategis

${ }^{1}$ Corresponding author:

Email: intan_azizka@apps.ipb.ac.id 


\section{INTRODUCTION}

TheUnited Nations Industrial DevelopmentOrganization (UNIDO) in 2017 stated that entrepreneurship has potential as one solution that can overcome three global problems, namely poverty, social inequality, and environmental problems. Entrepreneurship is considered to be a catalyst in responding to the challenges of sustainable development and as a driving force in overcoming employment problems, especially unemployment, economic growth, and the realization of positive impacts on the social environment (UNIDO, 2017). Entrepreneurship and innovation are the driving force for alleviating problems in terms of creating and providing jobs, economic growth, and efforts to realize positive impacts in the social sector. This is shown by the contribution of entrepreneurship in reducing poverty, employment problems, especially in employment, and strengthening the economy of a country. So a country needs to know the potential and development of entrepreneurship in the country.

Indonesia as a developing country whose entrepreneurship is dominated by Micro and Small Enterprises. The number of MSEs in Indonesia is 26 million and is dominated by the trade sector as much as 46.40 percent (BPS, 2019). West Java Province is the center of the trade sector in Indonesia with several businesses of around 2.18 million or equivalent to 17.80 percent of the total category (BPS, 2018). This shows that the trade sector is a leading sector and has very high potential and growth in Indonesia, especially in West Java. This is supported by Dcode Economic And Financial Consulting research in 2020 which states that the trade sector, especially retail, is ranked second from all sectors affected by the covid-19 pandemic. This shows that retailing can survive the drastic changes in the business environment.

Bogor City has unique characteristics compared to other areas. With an area of no more than $118.5 \mathrm{~km} 2$, the trade sector contributes the highest Gross Regional Domestic Product (GRDP) compared to other sectors, which is around 20.7 percent of the total GRDP of Bogor City BPS of Bogor City, 2020). This shows the development of retail or retail trade into an economic activity that has more contribution in the city of Bogor. In addition, the trade sector is one of the largest economic structures in Bogor City. Based on the Bogor City Industry and Trade Office in 2018, modern retail in Bogor City reached 540 retails.
Retail is one of the sectors that touch people directly in meeting their daily needs. Retail is divided into two namely traditional retail and modern retail. The development of modernization trends that occur in every aspect of life is also a driving factor for the growth of modern retail in Indonesia (BPS 2018). In addition, the difference between traditional markets and modern retail shows that modern retail has more complex business structures and processes (Levy and Weits, 2012). This is because retail strives to carry out business activities efficiently and effectively in increasing the value of products and services for consumers. One of the most influence in purchasing decisions and innovation according to the ability of SMEs is service innovation (Dewi et al. 2017). On the other hand, retail has a retail mix in an effort to achieve its goals. So that more planning is needed in every business process that takes place compared to traditional markets which still have some weaknesses and maintain conventional ways of buying and selling products.

Retail growth has made competition and changes in the retail business environment even higher. In the face of uncertain business competition, demanding retail to move quickly in maximizing existing opportunities. It has proven time and again that businesses should be too quickly innovative, change and transform to maximize the impact of a fast changing marketplace (Lee and Pati, 2017). One effort to maximize opportunities is to create business excellence (Soliha, 2018). The combination of the creation of a business opportunity (opportunity-seeking activities) with the management and creation of business excellence (advantage seeking activities) is a theory of strategic entrepreneurship. The latest theory from strategic management adds the Input-Process-Output segment to deepen understanding related to strategic entrepreneurship. In addition, it also explains related to value creation aimed at the social environment, organizations, and individuals involved in the organization (Hitt et al. 2001). Strategic entrepreneurship also has many different areas of implementations: strategic renewal, sustained regeneration, domain redefinition, organizational rejuvenation and business model reconstruction (Moris et al. 2010).

Based on the description above, it shows that the sustainability of retail needs to be designed as strategic planning. One method used is to use strategic entrepreneurship to maximize opportunities in facing 
retail competition and win the retail business sector's competitiveness in the city of Bogor. This study aims to analyze the characteristic of the retail business sector in Bogor City, strategic entrepreneurial factors and the influence between Input-Process-Output segmentation to maximize opportunities by creating competitiveness in the business processes of retail.

\section{METHODS}

This research using quantitative research (Misbahudin, 2013). The sampling method used is using nonprobability using purposive sampling technique (Fatihudin, 2015). Researchers use two types of data. First is the primary data obtained through the process of filling out questionnaires directly and/or online as well as interviews with respondents. Respondents referred to in this research are the owners or top management of modern retail in the City of Bogor. Second is secondary data from various works of literature related to research topics. The literature used by researchers is derived from books, journals, news, and various sources that can be accounted for the truth of the data obtained. This research was conducted from December 2019 to May 2020 with a total of 85 retail respondents from the total retail population in Bogor City of 540 modern retail. The number of respondents obtained using the Slovin formula with an error rate of 10 percent (Umar, 2003). From 85 respondents data obtained, it is known that data distribution includes 1 respondent from a supermarket, 2 respondents from department stores, 14 respondents from minimarket, 9 respondents from food and drug retail, and 59 respondents from speciality stores.

In data analysis, this research uses descriptive analysis to determine the implementation of strategic retail sector entrepreneurship in the city of Bogor by using the mean. The tool used in the processing of descriptive analysis data is using Microsoft Excel 2016. The descriptive analysis uses a Likert scale with a range of $1-5$. Scale range calculation using.

$$
\mathbf{R S}=((\mathbf{m}-\mathbf{n})) / \mathbf{b}
$$

Explanation: RS (Scale range); $\mathrm{m}$ (The highest number of alternative scores); $\mathrm{n}$ (The lowest number of alternative scores); $b$ (Number of classes)

Based on these formulas it is known that the calculation of the scale range used is 0.8 . The average range of 1.00
- 1.80 falls into the Poor category,> $1.80-2.60$ falls into the Fair category, $>2.60-3.40$ falls into the Good category, $>3.40-4.20$ falls into the Very Good category, and $>4.20-5.00$ falls into the Excellent category towards the statement on the research questionnaire.

In addition, this research also uses influence analysis Partial Least Square Structural Equation Model (PLS-SEM) is used to measure the effect between the independent variable and the dependent variable (Ramadiani et al. 2018). In the PLS-SEM analysis using the SmartPLS 3 application. This research using a significant level of 5 percent to obtain at-table 1.669. This research using six latent variables which are divided into three segments and 41 indicators. The input segment consists of three latent variables namely environmental factors (X1), organizational resources (X2), and individual resources (X3). In the process segment, there is a variable latent resource orchestration (X4). In the output segment, there are two variables, namely the variable creating value and competitive advantage (X5) and creating wealth and other benefits (Y1).

In PLS-SEM data analysis there are two evaluation models, namely the outer model evaluation and the inner model (Ramadiani et al. 2018). Outer models are used to determine the effect of indicators with latent variables. In the outer model evaluation, there are three tests. A convergent validity test is used to measure how much manifest variables can describe latent variables by looking at loading factors above 0.50 . The discriminant validity test is used to find out how big is the difference between manifest variables and latent variables with Average Variance Extracted (AVE) values above 0.50. Testing composite reliability by looking at the value of composite reliability and alpha cronbach above 0.60 . The inner model is used to determine the effect of the independent variable with the dependent variable by testing the coefficient of determination (R square) and the path coefficient (Ghazali and Latan, 2015). From the research model in Figure 1, the hypothesis in this research are:

H1: Environmental Factors have a significant effect on Resource Orchestration

H2: Organizational-Resource has a significant effect on Resource Orchestration

H3: Individual-Resource has a significant effect on Resource Orchestration

H4: Resource Orchestration has a significant effect on Customer Value and Competitive Advantage 
H5: Customer Value and Competitive Advantage has a significant effect on Creating Wealth and Other Benefits.

\section{RESULTS}

This research tested the validity and reliability using the IBM Statistical Package for the Social Science version 25 application. This test conducted using 31 samples to determine the level of validity and reliability of the questionnaire used in the research. Based on the test results, it can be seen that all variables in this research are declared "Valid". That is because the $\mathrm{R}$ on each variable exceeds or is greater than $\mathrm{R}$ table. Where in this validity test a sample of 31 samples is used so that the $\mathrm{r}$ table used as a standard is 0.3610 using a significance level of 5 percent. As for the reliability test, the Cronbach alpha value must be greater than 0.6 so that the variable can be declared reliable. Based on the calculation of a reliable test, informed that all variables can be declared "Reliable".

\section{Respondent Characteristic}

Based on demographic data from 85 respondents showed that female respondents (43.53\%) and men (56.47\%) had a difference that is not too far away. This indicates that both men and women have the same opportunity to occupy a position in the sector retail business. In addition, the retail business sector is dominated by the age of 20-25 years in minimarkets, food and drug retail, and speciality stores by $48.24 \%$. While supermarkets and department stores are dominated by respondents with an age of more than 40 years by $7.06 \%$. In the criteria of the position of respondents, dominated by assistant managers at $29.41 \%$ and shop heads at $24.71 \%$. In the latest education criteria, it shows that it is dominated by high school graduates of an equal level of $62.35 \%$ then followed by respondents with a bachelor level of $32.94 \%$. This shows that the retail business sector in the city of Bogor applies the same opportunity to occupy a position.

\section{Descriptive Analysis Results}

The results of the descriptive analysis show that the input segments of the three variables have been going very good (Table 1). In the total mean environmental factors variable, 3.839, this shows that retail in Bogor City is able to identify and optimize the opportunities contained in the retail sector business environment well. The total mean organizational resources variable is 4.138 , it shows that in managing internal retail business resources, it has run well. This can be applied by building a positive retail culture and encouraging progress by applying entrepreneurial-based leadership.

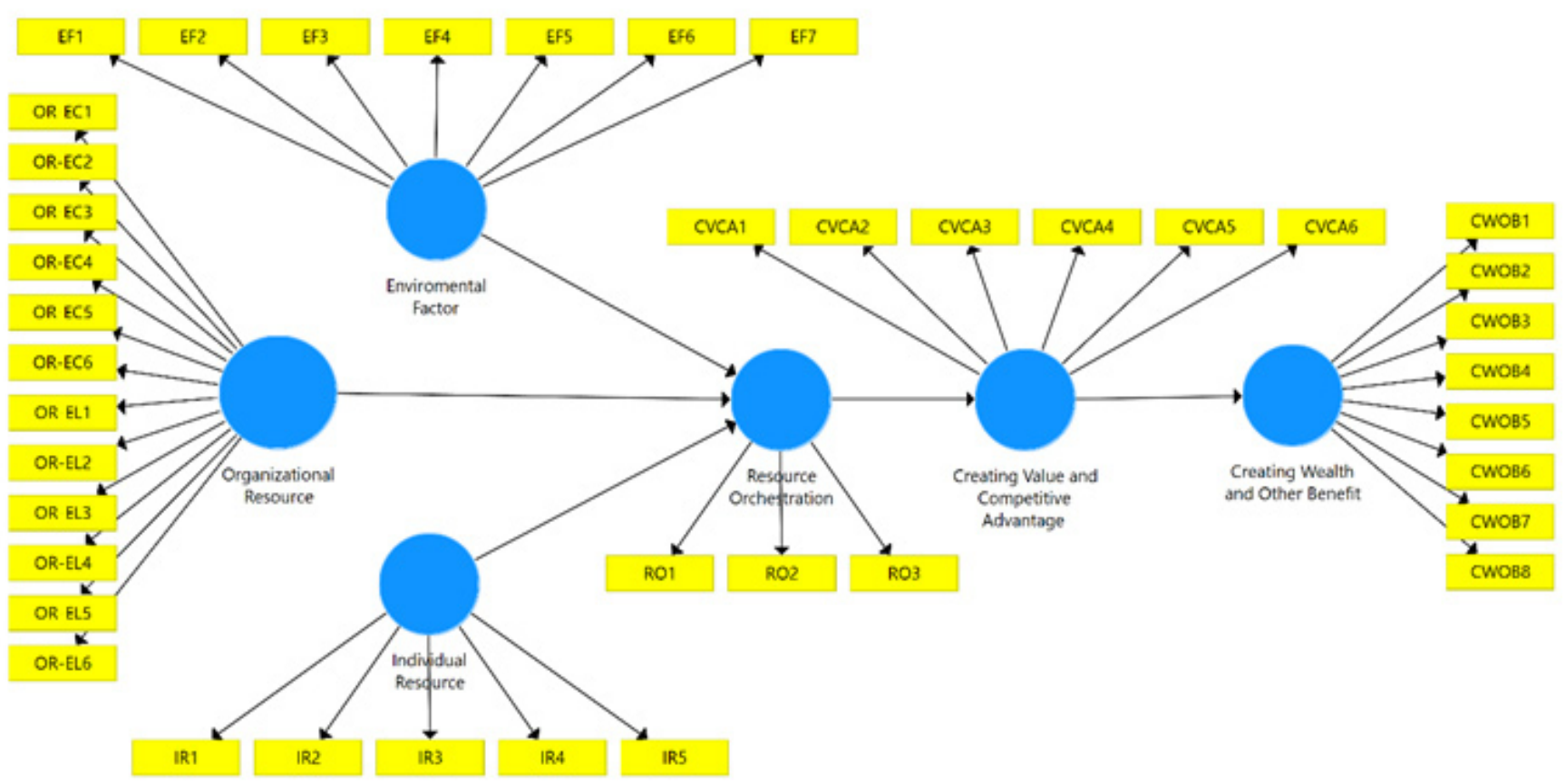

Figure 1. Research model 
Table 1.Descriptive analysis results of the implementation of strategic entrepreneurship in the retail business sector in the city of Bogor

\begin{tabular}{|c|c|c|c|}
\hline Variabel Latent & Indicators & Mean & Conclusion \\
\hline \multirow{8}{*}{$\begin{array}{l}\text { Environmental } \\
\text { Factors (X1) }\end{array}$} & Consumer demand & 3.682 & Very good \\
\hline & Business environment & 3.965 & Very good \\
\hline & Capital access & 3.635 & Very good \\
\hline & Fulfillment of resource & 4.000 & Very good \\
\hline & Service complexity & 3.847 & Very good \\
\hline & Marketing complexity & 3.894 & Very good \\
\hline & Operational complexity & 3.847 & Very good \\
\hline & Total Mean & 3.839 & Very good \\
\hline \multirow{13}{*}{$\begin{array}{l}\text { Organizational } \\
\text { Resource (X2) }\end{array}$} & New ideas and creativity are expected & 4.306 & Excellent \\
\hline & Risk Taking & 3.906 & Very good \\
\hline & Failure is tolerated & 4.000 & Very good \\
\hline & Learning is promoted & 4.165 & Very good \\
\hline & Product, process, and administrative innovations are championed & 4.259 & Excellent \\
\hline & Continuous change is viewed as a conveyor of opportunities & 4.047 & Very good \\
\hline & Nourish an entrepreneurial capability & 4.035 & Very good \\
\hline & Protect innovations threatening the current business & 4.188 & Very good \\
\hline & Make sense of opportunity & 4.365 & Excellent \\
\hline & Question the dominant logic & 4.106 & Very good \\
\hline & Revisit the "deceptively simple question" & 4.224 & Excellent \\
\hline & Link entrepreneurship and strategic management & 4.059 & Very good \\
\hline & Total Mean & 4138 & Very good \\
\hline \multirow{6}{*}{$\begin{array}{l}\text { Individual } \\
\text { Resource (X3) }\end{array}$} & Recognising opportunity & 4.188 & Very good \\
\hline & Entrepreneurial alertness & 4.153 & Very good \\
\hline & Real option logic & 4.153 & Very good \\
\hline & Entrepreneurial framework & 4.271 & Excellent \\
\hline & Opportunity Register & 3.835 & Very good \\
\hline & Total Mean & 4.120 & Very good \\
\hline \multirow{4}{*}{$\begin{array}{l}\text { Resource } \\
\text { Orchestrations } \\
\text { (X4) }\end{array}$} & Structuring the resource portofolio & 3.965 & Very good \\
\hline & Bundling Resource & 4.165 & Very good \\
\hline & Leverage capability & 3.953 & Very good \\
\hline & Total Mean & 4.028 & Very good \\
\hline \multirow{6}{*}{$\begin{array}{l}\text { Creating Value } \\
\text { and Competitive } \\
\text { Advantage (X5) }\end{array}$} & Customer relationship & 4.424 & Excellent \\
\hline & Different services & 4.259 & Excellent \\
\hline & Business cost & 3.870 & Very good \\
\hline & Differentiation & 4.471 & Excellent \\
\hline & Focus & 4.165 & Very good \\
\hline & Total Mean & 4.238 & Excellent \\
\hline \multirow{9}{*}{$\begin{array}{l}\text { Creating Wealth } \\
\text { and Other } \\
\text { Benefits (Y1) }\end{array}$} & Payment of Taxes & 4.412 & Excellent \\
\hline & Creating new jobs & 4.329 & Excellent \\
\hline & Equal opportunity for employees & 4.235 & Excellent \\
\hline & Adapt to market development & 4.306 & Excellent \\
\hline & Organizational Benefit & 4.235 & Excellent \\
\hline & Personal satisfaction & 4.212 & Excellent \\
\hline & Increased insight and skill & 4.341 & Excellent \\
\hline & Personal well-being & 4.189 & Very good \\
\hline & Total Mean & 4.282 & Excellent \\
\hline
\end{tabular}


In the individual variable total mean is 4.120 , it shows that retail is able to explore internally from the business sector, especially in shaping an entrepreneurial mindset through the culture that is applied to retail in Bogor City properly. The total mean resource orchestration variable is 4.028. It shows the management of resources from identification, grouping, and efforts to determine strategies to mobilize the capabilities of the resources they have in maximizing opportunities in the retail business sector. Efforts to create value for consumers and create business excellence are already going excellent. In the variable creating wealth and other benefits, the total mean of 4.282 shows that retail can manage the business system to create wealth and other benefits excellently. In addition to creating wealth, other benefits investigated include benefits in terms of social, organizational, and social.

\section{Analysis Results}

Based on the evaluation outer model (Table 2), is known that the convergent validity test of the 41 indicators studied there is one indicator that does not meet the loading factor value of 0.50 . The indicator is a cost leader indicator (CVCA 3) with an indicator value of 0.350 so it is removed from the research model. In the discriminant validity test, all latent variables have an AVE value of more than 0.50 .

In the composite reliability test, it is known that all latent variables have fulfilled the requirements of the composite reliability and alpha cronbach values of
0.60. So it can be concluded that the research model can be declared valid and reliable by removing one cost leader indicator from the variable creating value and competitive advantage. Evaluation of the inner model is done by looking at the value of $\mathrm{R}$ square and path coefficients. $\mathrm{R}$ square value is used to determine how strong the influence of exogenous variables on endogenous variables.

From the test results, it is known that the value that the $\mathrm{R}$ square value of the input segment which includes variables environmental factors, organizational resources, and individual resources is able to explain 41.9 percent of variable resource orchestration (Table 3 ). In the process segment variable resource orchestration is able to explain 19.6 percent of the variables creating value and competitive advantage. In the output segment, the variable creating value and competitive advantage are able to explain 52.2 percent of the variable creating wealth and other benefits.

Testing the path coefficient (path coefficient) (Table 4) is done by doing the bootstrapping procedure to find out the significance of the hypothesis used in the research. In this test using the t-statistic value. The hypothesis will be accepted if the t-statistic value is greater than the $t$-table value of 1.669. From the test results, it is known that environmental factors have a significant effect on orchestration resources because they have a $\mathrm{t}$-statistic value greater than $\mathrm{t}$-tables which is valued at 2.309 so $\mathrm{H} 1$ is accepted.

Table 2. Result outer model

\begin{tabular}{lccc}
\hline & AVE & Composite reliability & Alpha Cronbach \\
\hline Environmental factors & 0.506 & 0.877 & 0.839 \\
Organizational resource & 0.506 & 0.924 & 0.910 \\
Individual resource & 0.578 & 0.871 & 0.814 \\
Resource orchestration & 0.571 & 0.798 & 0.624 \\
Customer value and competitive advantage & 0.605 & 0.881 & 0.829 \\
Creating wealth and other benefit & 0.541 & 0.904 & 0.878 \\
\hline
\end{tabular}

Table 3. Result R square

\begin{tabular}{lc}
\hline Variabel dependen & R Square \\
\hline Customer value and competitive advantage & 0.196 \\
Creating wealth and other benefits & 0.522 \\
Resource orchestration & 0.419 \\
\hline
\end{tabular}


Table 4. Path coefficient

\begin{tabular}{|c|c|c|c|c|c|}
\hline Path & Hypothesis & $\begin{array}{l}\text { Original } \\
\text { Sample }\end{array}$ & T-Stat & P-values & Conclusion \\
\hline Environment factors $\rightarrow$ Resource orchestration & $\mathrm{H} 1$ & 0.237 & 2.039 & 0.042 & Significant \\
\hline Organization resource $\rightarrow$ Resource orchestration & $\mathrm{H} 2$ & 0.371 & 1.935 & 0.054 & Significant \\
\hline Individual resource $\rightarrow$ Resource orchestration & $\mathrm{H} 3$ & 0.152 & 0.869 & 0.385 & Not Significant \\
\hline $\begin{array}{l}\text { Customer value and competitive advantage } \rightarrow \\
\text { Creating wealth and other benefits }\end{array}$ & $\mathrm{H} 4$ & 0.442 & 4.553 & 0.000 & Significant \\
\hline $\begin{array}{l}\text { Resource orchestration } \rightarrow \text { Customer value and } \\
\text { competitive advantage }\end{array}$ & H5 & 0.723 & 14.238 & 0.000 & Significant \\
\hline
\end{tabular}

The effect of organizational resources on orchestration resources proved to be significant. This is indicated by the t-statistic value of 1.935 which is greater than the t-table of 1.669 so that $\mathrm{H} 2$ is accepted. The effect of individual resources on orchestration resources is proven to have a positive effect. This can be seen from the path coefficient value of 0.152 . However, the effect is not significant. This is indicated by the t-statistic value smaller than 1.669 which is equal to 0.869 so that $\mathrm{H} 3$ is rejected. In this research, it is proven that resource orchestration has a significant effect on creating value and competitive advantage. This is indicated by the t-statistic value greater than 1.669 which is 4.553 so that $\mathrm{H} 4$ is accepted. In this research, proven creating value and competitive advantage has a positive effect on creating wealth and other benefits. This is indicated by the t-statistic value much greater than 1.669 which is 14.283 so that $\mathrm{H} 5$ is accepted.

From the test results it is known that in the input segment, environmental factors have a significant effect on resource orchestration. The environment are the regional, physical, psychological and social environment of the entrepreneur (Grundsten, 2004). Environmental factors have two possibilities, namely as strengths or weaknesses for retailers in facing competition and efforts to develop retail business processes. To be able to maximize environmental factors into strengths for retail, efforts are needed to identify changes in the business environment that occur in the retail business sector. In addition, it is necessary to identify the resources available to meet the needs of resources used in retail business processes and understand the level of complexity of retail marketing, service and operational processes (Revilla et al. 2008). Based on the results of the descriptive analysis shows that retail in Bogor is still not optimal in finding detailed information related to access to capital from banks or investors.
In organizational resources, there are two important elements, namely entrepreneurial culture and entrepreneurial mindset (Ireland et al. 2003). The role of the retail owner or leader has a significant share, especially in preparing management and employees to implement a culture that supports the development of both the ability of employees, the application of ideas and innovations in retail (Covin and Slevin, 2002; Utoyo et al. 2019). In the other hand, an entrepreneur can create new wealth-producing resources or endows existing resources for creating wealth (Drucker, 2002). An entrepreneurial environment will not only inspire employees to innovative but also motivate them to develop an entrepreneurial mindset, one that crucial to the success of the business (Cho and Lee, 2018). This will affect the success of the management of resources owned by retail to be efficient and effective. However, according to the results of the descriptive analysis shows that retail in the city of Bogor is still not optimal in providing opportunities for employees to take risks regarding to their duties and authority in their work.

The individual resource variable on resource orchestration proved to have a positive but not significant effect. This shows that retail in Bogor City tends not to be optimal in managing information related to market development to obtain new opportunities and tends to be not optimal in assessing the strengths and weaknesses of product innovation offered. Researchers argue this is because the management is dominated by the age of 20-25 years and high school graduates where their experience and abilities are not optimal, especially in retail management related to decision making and strategic management. Thus, it is necessary to set specific standards in the selection of management. Based on the results of the descriptive analysis shows that retail in the city of Bogor is still not optimal in managing information opportunities in the retail business sector in the city of Bogor. Retail needs to concentrate on the joint function of individual 
and organizational factor. Individual factors will merge with organizational factors (Brazeal, 1993).

The resource orchestration variable has a significant effect on creating value and competitive advantage. The process of identifying, creating portfolios, grouping, improving and enhancing the capability of resources owned by retailers has an important role in the process of determining the strategy in the application of creating value and competitive advantage in retail. In addition, a combination of input segments will provide alternative strategies that can be used by retail. Based on the results of the descriptive analysis shows that retail in the city of Bogor has not been maximally committed to improving the ability of its resources. So it is necessary to formulate programs that support employees in improving employee insight and abilities.

The variable creating value and competitive advantage have a positive effect on creating wealth and other benefits. This shows that efforts to create consumer value and product competitiveness have a strong influence on wealth creation and other benefits. This is in accordance with the theory of strategic entrepreneurship (Hitt et al. 2011). However, according to descriptive assessments, it is necessary to increase the service efforts provided to consumers and segmentation analysis of the products offered. The retail competitive edge can be predicting consumer behaviour and there is still too much to be explored regarding a corporate entrepreneurial (Kuratko, 2009).

\section{Managerial Implications}

The result of the analysis of the influence of the implementation of the strategic entrepreneurship retail business sector in the city of Bogor shows that of the three input-process-output segments, the variable creating value and competitive advantage has the most significant effect on creating wealth and other benefits. So retailers need to maximize retail efforts in creating value to consumers through improved service and customer relations. In addition, retail in Bogor City needs to have a strategy in making business excellence by knowing the needs and desires of customers.

The management in the retail business sector in Bogor City is expected to be able to improve and optimize two aspects, namely aspects of the retail business system and retail employees. In the aspect of the retail business system, it is necessary to integrate the entrepreneurial actions that are applied with strategy management. This can be done by knowing and implementing an omnichannel to improve retail management systems(Verheof et al. 2015). Includes system integration, product management, inventory management and product ordering, data monitoring, customer management, business analysis and most importantly, in increasing consumer purchases and making it easier for consumers to improve their image retail to consumers. In addition, it is necessary for retailers in Bogor City to create a standard consumer service that is applied to retails to increase trust and repurchase rates by consumers.

On the other hand, retailers need to know and maximize the potential and capability of their resources, especially labor. This can be achieved by building and implementing a culture of agility, adaptive, and flexible behavior as a basis for employees in dealing with a changing environment in line with modernization and digitalization. In addition, employees are also prepared to be able to adapt to follow the strategies used by retailers in facing business competition so as to achieve retail goals in the City of Bogor.

\section{CONCLUSIONS AND RECOMMENDATIONS}

\section{Conclusions}

The implementation of retail strategic entrepreneurship in the city of Bogor according to the results of a descriptive analysis shows that the input segment which includes three variables, namely environmental factors, organizational resources, and individual resources and the process segment namely resource orchestration in the implementation of retail strategic entrepreneurship in the city of Bogor has been going very good. In the output segment there are two variables, namely the variable creating value and competitive advantage and creating wealth and other benefits are running excellent. Based on the results of an analysis of the influence of the implementation of strategic entrepreneurship in the retail business sector in Bogor City, it shows that in the three input-process-output segments, the variable creating value and competitive advantage has the most significant effect on creating wealth and other benefits. 


\section{Recommendations}

Future studies are suggested to conduct research by analyzing different objects, namely traditional markets or non-store retailing. In addition, with the development of digitalization, it will be possible to add innovation variables in subsequent studies as one of the variables in the output segment.

\section{ACKNOWLEDGEMENT}

Researcher would like to express special thanks for DITMAWA IPB University for providing support in the implementation of International Seminars and journal publishing.

\section{REFERENCES}

[BPS] Badan Pusat Statistik. 2019. Analisis hasil SE2016 lanjutan potens peningkatan kinerja usaha mikro kecil. http://www.bps.go.id.

[BPS] Badan Pusat Statistik. 2018. Hasil pendataan usaha/perusahaan besar dan eceran; reparasi dan perawatan mobil dan sepeda motor. Sensus Ekonomi 2016-Lanjutan. http://www.bps.go.id.

[BPS] Badan Pusat Statistik Kota Bogor. 2020. Produk domestik bruto kota bogor menurut pengeluaran 2015-2019 http://www.bogorkota.bps.go.id.

Brazeal DV. 1993. Organizing for internally developed corporate ventures. Journal of Business Venturing 8 (1): 75-90.

Cho YH, Lee JH. 2018. Entrepreneurial orientation, entrepreneurial education and performance. Asia Pacific Journal of Innovation and Entrepreneurship 12(2): 124-134.

Covin J, Slevin. 2002. The entrepreneurial imperatives of strategic leadership. In M.A. Hitt,

Ireland RD, Camp SM, Sexton DL. 2003. Strategic entrepreneurship: Creating a New Mindset. Oxford:Blackwell Publishers.

Dewi H, Maarif MS, Sunarti TC. 2017. Innovation strategy to improve the competitiveness of micro small, and medium enterprises of bandar lampung banana chips. Indonesian Journal of Business and Entrepreneurship (IJBE) 3(1): 64. https://doi.org/10.17358/ijbe.3.1.64.

Drucker PF. 2002. The discipline of innovation. Harvard Business Review 80(8): 95-104.

Fatihudin D. 2015. Metode Penelitian Untuk Ilmu
Ekonomi, Manajemen, dan Akuntansi. Sidoarjo: Zifatama Publiser.

Ghozali I, Latan H. 2015. Partial Least Square Konsep, Teknik, dan Aplikasi Menggunakan Program SmartPLS 3.0. Semarang: Badan Penerbit Universitas Diponegoro

Grundstén H. 2004. Entrepreneurial Intentions and the Entrepreneurial Environment: A Study of Technology-based New Venture Creation. Helsinki: Helsinki University of Technology.

Hitt MA, Ireland RD, Camp SM, Sexton DL. 2001. Strategic entrepreneurship: entrepreneurial strategies for wealth creation. Strategic Management Journal 22(6-7): 479-491. https:// doi.org/10.1002/smj.196.

Hitt MA, Ireland RD, Sirmon DG, Trahms C. 2011. Strategic Entrepreneurship: Creating Value for individuals, Organization, and Society. Academy of Management Perspectives.

Ireland RD, Hitt MA, Sirmon DG. 2003. A model of strategic enterpreneurship: the construct and its dimensions. Journal of Management 29(6): 963-989. https://doi.org/10.1016/S01492063(03)00086-2.

Kuratko DF. 2009. Entrepreneurship, Theory, Process, and Practice. South-Western Cengage Learning, Masson, $\mathrm{OH}$.

Lee J, Pati N. 2017. A study of the effect of corporate diversification strategy on technological innovation and strength in technology-oriented multinational corporations across countries. International Journal of Business Innovation and Research 13(1): 1-29.

Levy M, Weitz B. 2012. Retailing Management 8th edition. New York: McGraw-Hill/Irwin.

Morris M, Kuratko D, Covin J. 2010. Corporate Entrepreneurship and Innovation. Boston: Cengage Learning.

Ramadiani A, Hidayanto AN, Halya HR, Khairina DM, Maharani S. 2018. Model dan Bentuk Penelitian E-Learning Menggunakan Structural Equatin Model. Samarinda: Mulawarman Univesity PRESS.

Revilla E, Prieso IM, Rodriguez B. 2008. Dynamism and complexity as antecedents of the knowledge strategy in product development. IE Business School Working Paper DO8-143-I.

Soliha E. 2008. Analisis Industri Ritel di Indonesia. Jurnal Bisnis dan Ekonomi (JBE) 15(2): 128142.

UNIDO. 2017. United Nations Industrial Development 
Organization. Retrieved from www.unido. org: https://www.unido.org/news/weif-2017entrepreneurship-and-innovation-are-essentialachieve-sustainable-development-goals.

Umar H. 2003. Metode Penelitian untuk Skripsi dan Tesis Bisnis. Jakarta: PT Raja Grafindo Persada.

Utoyo I, Fontana A, Satrya A. 2019. The role of entrepreneurial leadership and configuring core innovation capabilities to enhance innovation performance in a disruptive environment. International Journal of Innovation Management 2050060. doi:10.1142/s1363919620500607.

Verhoef PC, Kannan PK, Inman JJ. From multi-channel retailing to omni-channel retailing. introduction to the special issue on multi-channel retailing. Journal of Retailing 91(2): 174-18. 